gies, export activity and training of employees. The growth of labor productivity is positively associated with firm size, investment activity, digitalization and R\&D spending. There is no positive and significant impact of innovation activities on productivity level and its dynamics, which may be a result of low innovation intensity and time lags in effects of innovation activities on revenue. The evidence suggests that innovative firms with positive dynamics of innovation performance are followers of foreign competitors. We find that firms with the leading and lagging levels of labor productivity have different strategies for human capital accumulation. Leading firms combine significant staff turnover with intensive professional development of existing staff, while lagging in productivity firms are not involved in staff turnover and investment in training. While leading in productivity firms compete for the best personnel, lagging firms compete for financial resources. In addition, leading companies find among the highest the risks that qualified personnel would be diverted, while the lagging companies find among the highest the risks of employees' low motivation. Most of the leading in productivity firms are interested in continuous improvements of labor productivity, while among lagging in productivity firms this problem is important only for one fourth of them. Lack of internal motivation to improve their productivity may reflect failures in the corporate governance system. At the same time, the established model of relations with the state has a significant impact on the respective motivations of companies.

Keywords: labor productivity, basic non-resource industries, factors of productivity growth, investments in fixed assets, innovation, REंD, digital technology, human capital.

JEL Classification: D22, J24, O31

DOI: $10.31737 / 2221-2264-2020-48-4-10$

H. Blöchliger

OECD, Paris, France

L. Wildnerova

OECD, Paris, France

\title{
Productivity of the Russian firms: Seven stylized facts
}

\begin{abstract}
Productivity in Russia has been falling steadily over the past 15 years. This paper explores firm-level data to understand the contribution of individual firms to aggregate productivity and summarizes findings in the form of seven stylized facts. Policies to address the productivity decline should focus on regulatory reform to strengthen market forces; create a climate that is supportive to innovative start-ups; help unproductive firms to leave the market earlier; foster labour and capital mobility and knowledge transfer between firms and across regional borders; and embrace foreign ownership. These policies should be complemented by targeted support to households and firms severely affected by the covid-19 crisis. This note is built on the findings of an OECD Economics Department Working Paper published in early 2020.
\end{abstract}

Keywords: Russian economy; firm-level productivity; productivity gap; foreign ownership; entry and exit of firms.

JEL Classification: D24, L16, O43.

DOI: $10.31737 / 2221-2264-2020-48-4-11$

\section{Negative trends in the productivity of the Russian economy}

The growth of potential output of the Russian economy has fallen dramatically from about $8 \%$ annually in 2000 to less than $1 \%$ in 2019 (Figure 1). Decomposing potential growth into the contributions from investment, employment, participation, total factor productivity and working-age population reveals that the main reason for the growth slowdown is rapidly declining productivity. In 2000 , productivity growth contributed to output growth by almost $6 \%$, while the contribution of productivity turned even negative after 2012. The Russian economy develops on the basis of growing employment and capital spending, while productivity is actually a drag on 


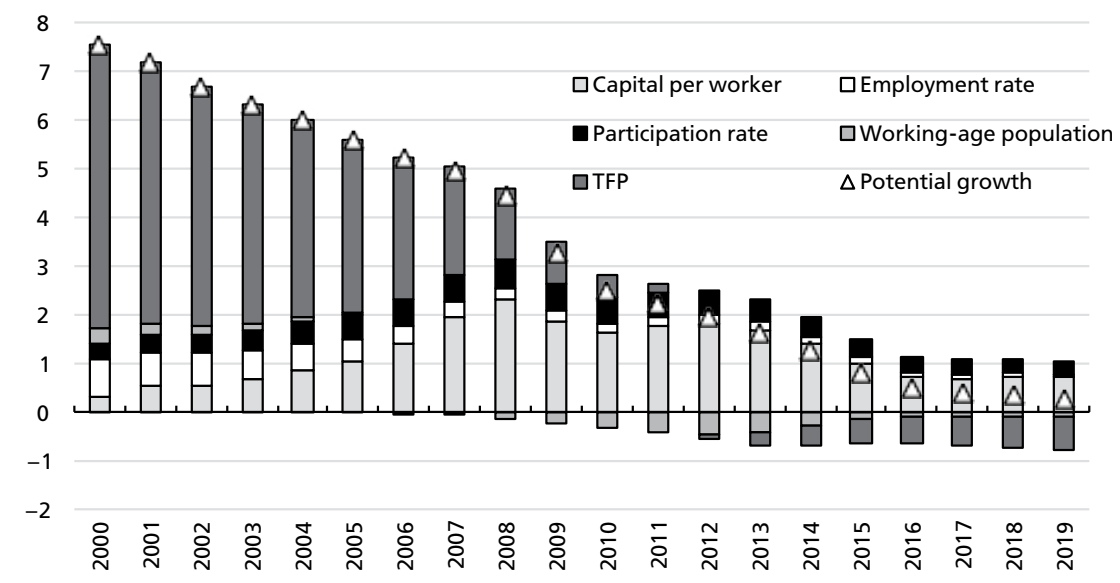

Figure 1

Potential growth over years

growth. The aim of this note is to explore economy-wide developments at the firm level and to establish a few stylized facts about productivity of Russian firms.

Most findings in this note rely on the yearly firm balance sheets provided by the OECD-Orbis database that collects the data from multiple sources for numerous countries. Data for Russia is reported since 2003. The dataset consists of around 5.8 million observations, making Russia the largest country in the OECD-Orbis database. Detailed information on sources, coverage within individual data sources as well as cleaning of the dataset is described in the working paper.

Financial information such as profits or value added, needed to compute total factor productivity, is lacking for most of the Russian firms. For that reason, the paper relies on labour produc-

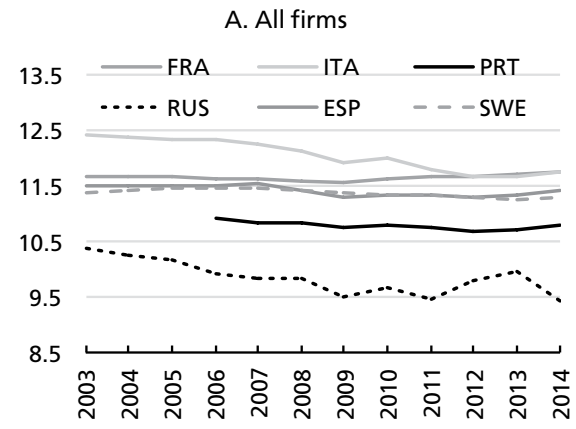

tivity or gross output per employee. One drawback of using labour productivity is that it does not enable us to distinguish between investmentdriven and technological-progress-driven productivity growth. Still, labour productivity is a robust measure to understand advancements and growth differences between firms as well as aggregate productivity developments.

\section{Stylized fact 1: The decline of firm-level productivity is broad-based}

The productivity of Russian firms lags behind other countries, and the gap has widened since 2003, although absolute values have to be taken with some care due to the PPP conversion (Figure 2). Trends are similar across different productivity aggregations and weighing procedures. Moreover, the average productivity of the

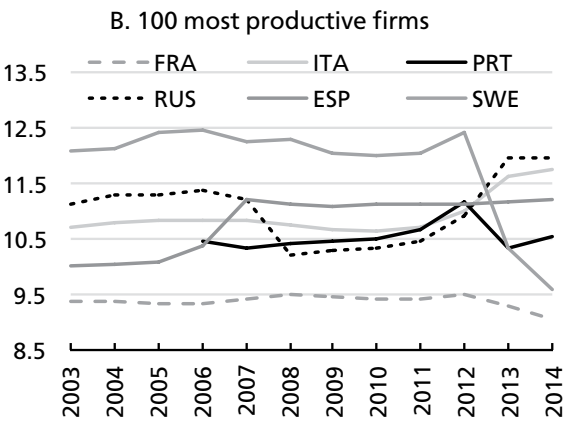

Figure 2

Productivity evolution in selected countries, averages, 2003-2014 


\section{A. Overall}

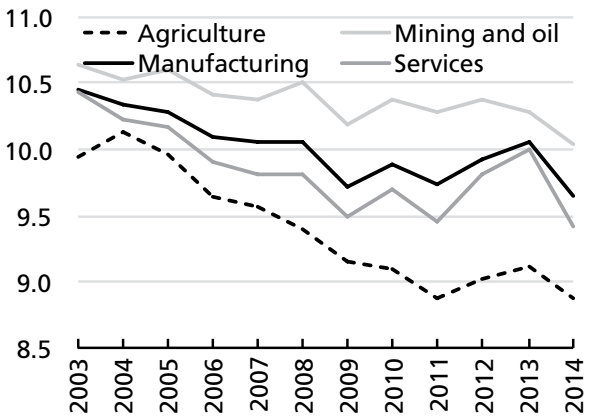

\section{B. Controlling for size and age}

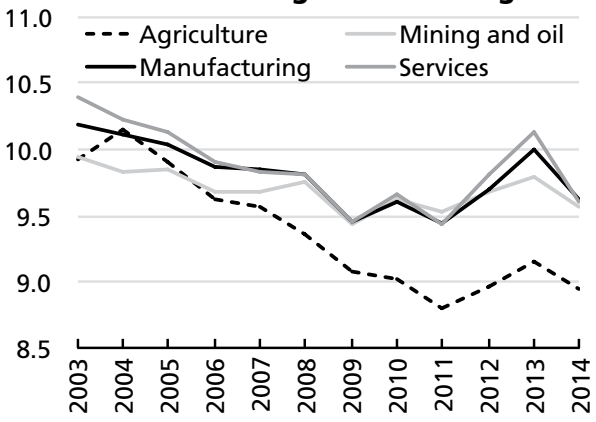

A. Over

B. Cont

Figure 3

Productivity of firms by sector, 2003-2014

100 most productive firms - which also tend to be more export-oriented - in each industrial sector is also declining and remains below productivity of the 100 most productive firms in other countries, suggesting a loss of competitiveness and export opportunities of the Russian firms.

Productivity fell in all industrial sectors between 2003 and 2014, and differences between sectors widened (Figure 3). Productivity in the agricultural sector had fallen most, and the gap between the average agricultural firm and firms in other sectors widened. Controlling for size and age, productivity differences between sectors become quite small, except for agriculture which remains the least productive sector of the Russian economy. The productivity decline is less pronounced in larger firms, with the exception of the services sector, where productivity of large firms fell more than those of small firms.

\section{A. Share of labour force}

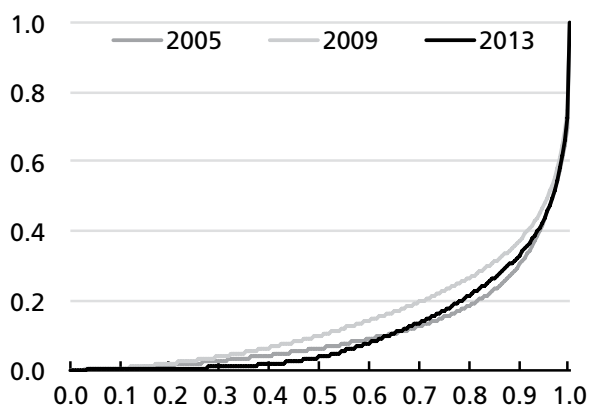

\section{Stylized fact 2: Russian markets are concentrated}

Markets in Russia are concentrated, and concentration has increased since 2003 (Figure 4). High market concentration partly reflects the legacy of the socialist period, although concentration also rose in other European countries (Bajgar et al., 2019). Ten percent of firms employ two-thirds of the workforce and produce almost $90 \%$ of the output. The Russian economy is more concentrated than a selection of European countries except France (Figure 5). Moreover, Russia has the smallest share of micro-firms of all countries, suggesting that new firms in Russia encounter particular difficulties to enter the market and to thrive. As such, the Russian economy might not fully exploit the potential of its entrepreneurs. Moreover, high market concentration could be responsible for the large wage and income inequality observed in Russia (OECD, 2017).

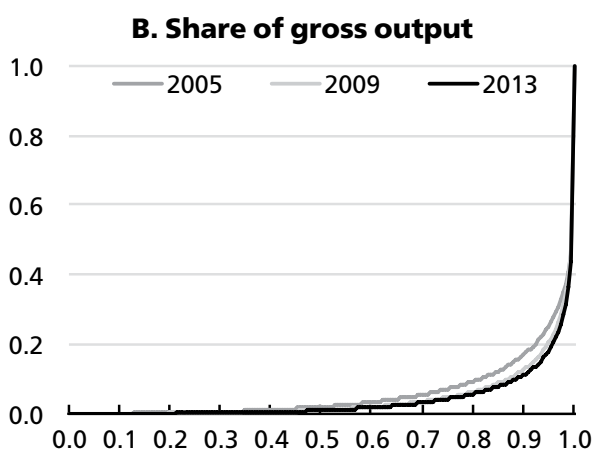

Figure 4

Distribution of labour and gross output across firms, by year 

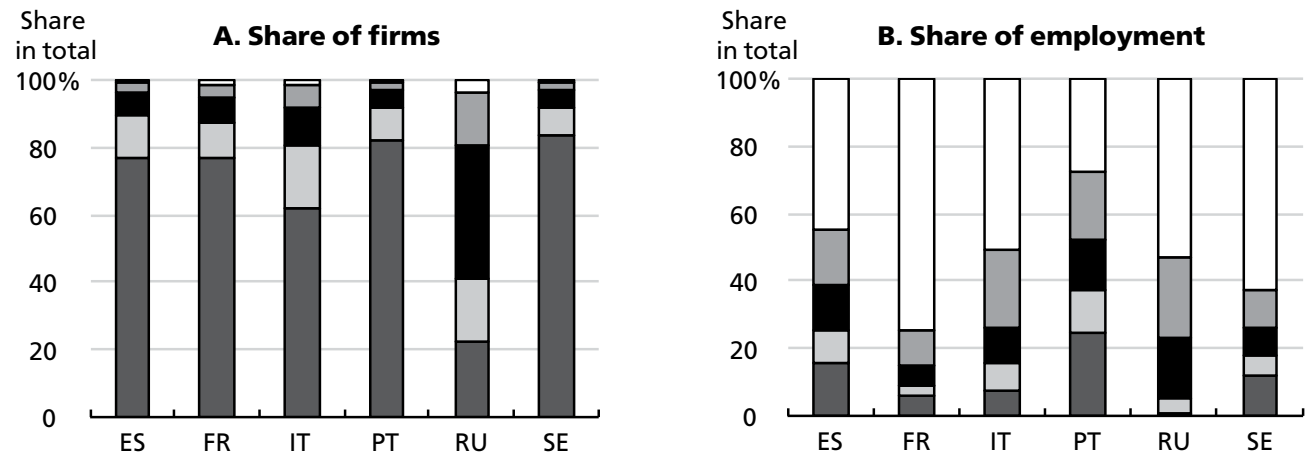

口Large 250+ $\quad \square$ Medium 50-249

Small 20-49

口V small 10-19

Micro 0-9

Figure $\mathbf{5}$

Employment and number of firms by firm size and country, 2010

Stylized fact 3: Large firms are more productive, but smaller ones catch up

Larger firms are generally more productive and less affected by the productivity decline between 2003 and 2014 (Figure 6). Russia's largest firms are still the country's most productive, and since large firms are better able to deal with shocks, productivity is less volatile. Still productivity of micro-firms grew strongly after 2009. Two factors could explain that. First, micro firms are more flexible and might improve productivity much faster than their larger counterparts, whether through boosting technical efficiency, innovation, or by reducing their workforce. Second, unproductive small firms leave the market more easily than large ones, with ever more productive new firms replacing the defunct ones. Since start-ups and young innovative firms con- tribute substantially to productivity growth and net job creation (Haltiwanger, Jarmin, Miranda, 2011), and since more than $60 \%$ of Russian firms have less than 20 employees, policies focused on innovative start-ups could have a considerable impact on growth.

\section{Stylized fact 4: The dynamics of "creative destruction" has slowed}

The percentage of firms entering the market each year has declined from around 15 to $9 \%$, while the percentage of exiting firms remained stable (Figure 7).

More firms enter than exit the market in total, but the difference has become smaller. As can be expected, exiting firms are the least productive (Figure 8). Despite high volatility, new entrants are the most productive, suggesting that
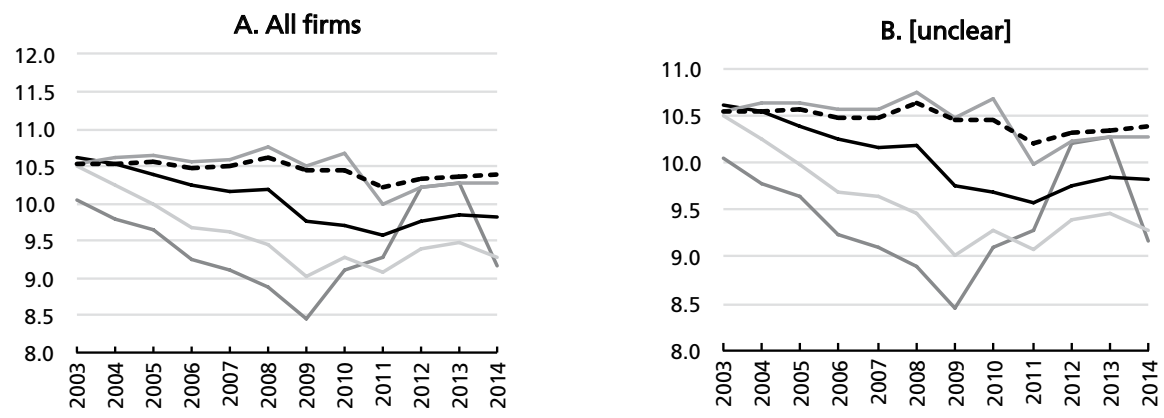

- Micro 0-9 $\longrightarrow$ small 10-19

Small 20-49

Medium 50-249 --.-.Large 250+

Figure 6

Productivity by firm size 


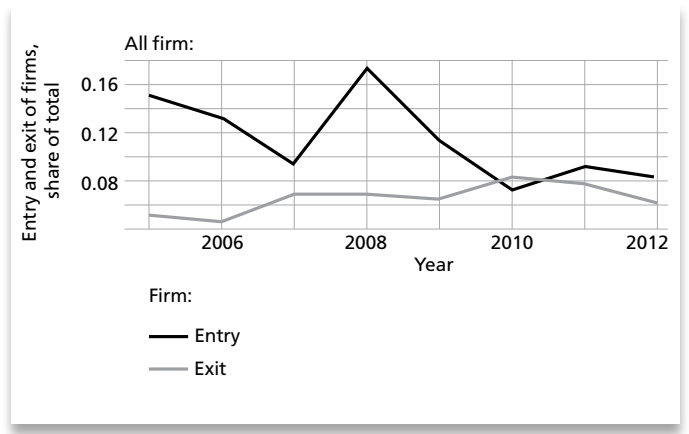

Figure 7

Exit and entry, 2005-2011

support to new innovative firms could raise economy-wide productivity. Still in sectors known for high entry costs and economies of scale, such as mining and manufacturing, older firms tend to be more productive on average than younger ones.

Low and declining productivity of older firms has consequences for the economy. While young unproductive firms leave the market after few years, older firms remain operating although productivity towards the end of their life declines below productivity of new firms (Figure 9). Especially firms aged between 10 and 20 years tend to have very low productivity when they finally leave, suggesting that too many old unproductive firms stay on the market for too long, putting a drag on growth. Against this background, policies to help exit old unproductive firms - sometimes called "zombie firms" - and foster resource real-

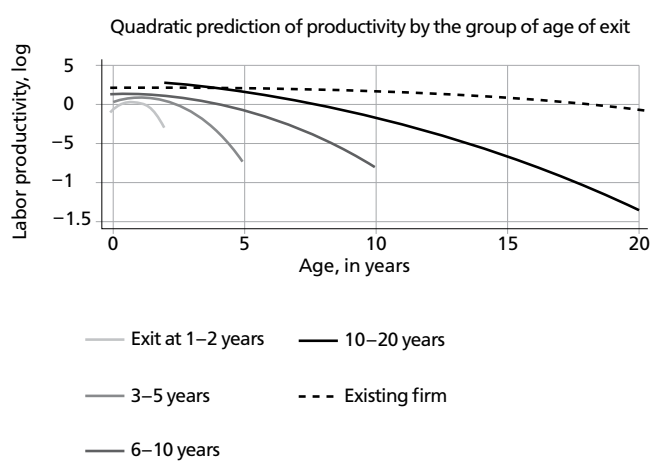

Figure 9

Productivity by the age of firm that exits economy

Source: OECD calculations based on OECD-Orbis data.

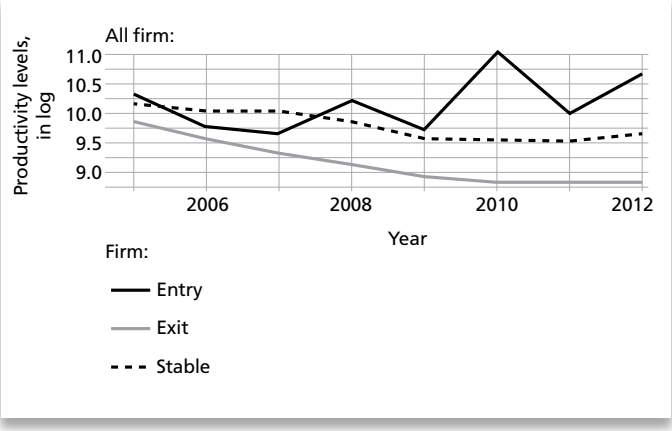

\section{Figure 8}

Productivity of firms that exit, enter and remain in the sample, 2005-2012

location towards younger, more productive firms could boost economic dynamism.

\section{Stylized fact 5: The gap between frontier firms and laggards has increased}

As in most OECD countries, the gap between the most productive and other firms had been widening in Russia until 2012 although it has narrowed a bit since then (Figure 10). The most productive firms reached almost similar productivity levels in 2014 than in 2003, while the productivity of median and laggard firms was declining almost incessantly. The rising productivity gap points to the need for policies that strengthen entry of new firms, exit of old and unproductive firms and knowledge transfer between all of them.

Russia suffers from the largest gap between the most and the least productive firms of all coun-

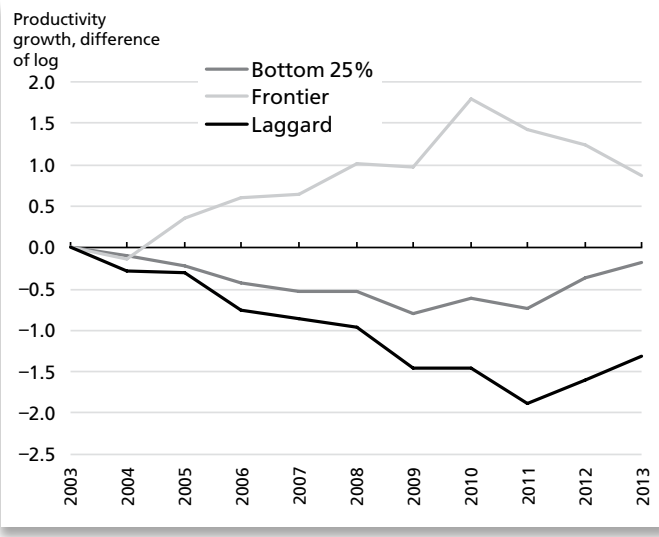

Figure 10

The gap between frontier firms and laggards has widened in Russia 


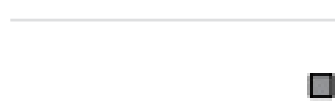

8

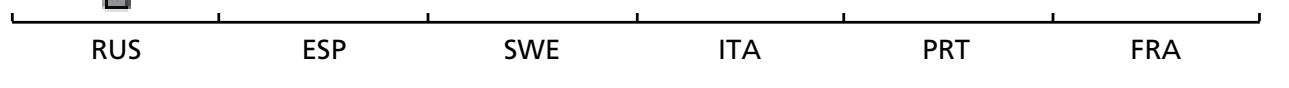

Figure 11

Productivity cut-offs by country

tries under scrutiny, with the most productive $5 \%$ being 60 times more productive than $5 \%$ of the least productive firms (Figure 11). In addition, the most productive firms in Russia lag behind their counterparts in other countries. Still the best performing Russian firms in such sectors as transportation and storage or some services are competitive in a European context. Finally, the productivity frontier group today consists of smaller and younger firms than in 2003.

\section{Stylized fact 6: Foreign ownership helps increase productivity}

Foreign firms tend to increase overall productivity of the economy (Table 1 ). With around 8000 foreign firms representing $1.6 \%$ of all firms in Russia in 2016, foreign firms make up around $4 \%$ of all frontier firms, while their share among laggard and bottom firms is only around 0.8 and $0.5 \%$ respectively.

The results of an econometric exercise can be summarized as follows.

- Foreign firms are on average $50 \%$ more productive (Column 1). If the firm is owned by an entity based in a European country, productivity rises by another $18 \%$. Ownership by entities from a country known as a 'tax haven' does not have an additional impact on productivity.

- When a Russian firm is bought by a foreign entity, its productivity rises by about $9 \%$ compared to its previous performance
(Column 2). If the firm is bought by an entity from a European country, productivity rises by another $2 \%$ (Column 3 ).

- Privatizing a state-owned enterprise (SOEs) does not make it more productive. The change in ownership might not imply a real transfer of control and change in practice, with little impact on productivity as a result. Research for an earlier observation period suggests that privatization tends to foster firm-level productivity (Brown, Earle, Telegdy, 2006).

- An increase of foreign firms in a region is associated with a rise in productivity of domestic firms in the same sector, suggesting that foreign competition and knowledge transfer generate a small positive spillover on domestic incumbents in the same sector (Column 5). Productivity in other sectors might decline, suggesting insufficient knowledge transfer and competition for human capital between sectors. The smaller the number of firms in a region, the lower productivity, again highlighting the productivity-enhancing effect of stronger competition between firms.

Overall domestic firms seem to benefit from exposure to international competition and gain technological knowledge, especially if they are in a supplier relationship with the foreignowned firm (Javorcik, Spatareanu, 2008; Javorcik, 2004). Domestic firms can also benefit if the for- 
Table 1

Ownership and productivity, econometric estimation

\begin{tabular}{|c|c|c|c|c|c|}
\hline \multirow{2}{*}{ Dependent variable } & \multicolumn{5}{|c|}{ Labour productivity, log } \\
\hline & (1) & (2) & (3) & (4) & (5) \\
\hline \multirow{2}{*}{ Foreign-owned firm } & $0.506^{* * *}$ & $0.0877^{* * * *}$ & $0.0507^{* * * *}$ & $0.0731^{* * * *}$ & \\
\hline & $(0.0650)$ & $(0.00864)$ & $(0.0185)$ & $(0.00922)$ & \\
\hline \multirow{2}{*}{$\begin{array}{l}\text { Foreign-owned by a firm from tax } \\
\text { haven }\end{array}$} & 0.0402 & & $0.0415^{* * *}$ & & \\
\hline & $(0.0614)$ & & $(0.0202)$ & & \\
\hline \multirow{2}{*}{$\begin{array}{l}\text { Foreign-owned by a firm from } \\
\text { European country }\end{array}$} & $0.179^{* * *}$ & & $0.0596^{* *}$ & & \\
\hline & $(0.0431)$ & & $(0.0245)$ & & \\
\hline \multirow{2}{*}{ State-owned firm } & & & & 0.309 & \\
\hline & & & & $(0.294)$ & \\
\hline \multirow{2}{*}{$\begin{array}{l}\text { Number of foreign firms in sector- } \\
\text { region, log }\end{array}$} & & & & & $0.0092^{* * * *}$ \\
\hline & & & & & $(0.00258)$ \\
\hline \multirow{2}{*}{$\begin{array}{l}\text { Number of firms in sector-region, } \\
\log \end{array}$} & & & & & $-0.0394^{* * * *}$ \\
\hline & & & & & $(0.00414)$ \\
\hline \multirow{2}{*}{$\begin{array}{l}\text { Number of foreign firms in } \\
\text { region, log }\end{array}$} & & & & & $-0.0267^{* * * *}$ \\
\hline & & & & & $(0.00408)$ \\
\hline \multirow{2}{*}{ Number of firms in region, $\log$} & & & & & $-0.110^{* * * *}$ \\
\hline & & & & & $(0.00874)$ \\
\hline \multirow{2}{*}{ No foreign firms in sector-region } & & & & & -0.0037 \\
\hline & & & & & $(0.00330)$ \\
\hline \multirow{2}{*}{ No foreign firms in region } & & & & & $-0.0225^{* *}$ \\
\hline & & & & & $(0.0111)$ \\
\hline \multirow{2}{*}{ Age } & $-0.0266^{* * *}$ & & & & \\
\hline & $(0.00749)$ & & & & \\
\hline \multirow{2}{*}{ Age, squared } & $0.0002^{* * * *}$ & & & & \\
\hline & $(4.29 \mathrm{e}-05)$ & & & & \\
\hline \multirow{2}{*}{ Employment, log } & $0.0958^{* * * *}$ & & & & \\
\hline & $(0.0229)$ & & & & \\
\hline Observations & 4479207 & 4419144 & 4419144 & 3931230 & 4328571 \\
\hline R-squared & 0.120 & 0.833 & 0.833 & 0.851 & 0.833 \\
\hline Sample & \multicolumn{4}{|c|}{ 2007-2014, all firms } & $\begin{array}{c}2007-2014, \\
\text { domestic } \\
\text { firms only }\end{array}$ \\
\hline Region controls & Yes & No & No & No & No \\
\hline Sector fixed-effect & Yes & No & No & No & No \\
\hline Year fixed-effect & Yes & Yes & Yes & Yes & Yes \\
\hline Firm fixed-effect & No & Yes & Yes & Yes & Yes \\
\hline
\end{tabular}

Note. Robust standard errors in parentheses. ${ }^{* * *} \mathrm{p}<0.01,{ }^{* *} \mathrm{p}<0.05,{ }^{*} \mathrm{p}<0.1$. The results report an average effect of the variable on the firm's productivity level.

Source: OECD-Orbis database. 
eign firm is technologically close to the domestic incumbent and subsequently encourages innovation to compete on the local market (Fons-Rosen et al., 2017).

\section{Stylized fact 7: Productivity varies a lot across regions}

Productivity is strongly determined by location and seems to be bound by regional idiosyncrasies, even controlling for industrial composition (Blöchliger, Durand-Lasserve, 2018). The North-West federal region is the most productive with $11 \%$ higher productivity than the Central federal region, including Moscow (Table 2). The least productive region, with $21 \%$ lower productivity than the Central federal region, is the North Caucasian District, which is also very sparsely populated. Against this background, policies that help foster capital and labour mobility and technology transfer across regional borders could help raise economy-wide productivity.

\section{Policies to help increase productivity}

This short paper used firm-level data to understand the characteristics of productivity levels and growth of Russian firms. Since the paper did not analyze the policy drivers of productivity, an empirically-sustained channel from policy to productivity outcomes is difficult to establish. Still the way the analysis has been carried out allows for a few general conclusions in terms of strategies, policies and measures to help firm-level productivity in Russia to rise. These are:

- Pursue a regulatory reform and competition strategy that helps strengthen market forces.

Table 2

A productive Russian firm: summary estimations

\begin{tabular}{|c|c|c|c|c|c|}
\hline \multirow{2}{*}{ Dependent variable } & \multicolumn{5}{|c|}{ Labour productivity, log } \\
\hline & (1) & $(2)$ & (3) & (4) & (5) \\
\hline \multirow{2}{*}{ Size of firm (employment), log } & $0.0877^{* * * *}$ & & $0.114^{* * * *}$ & $0.110^{* * * *}$ & $0.122^{* * *}$ \\
\hline & $(0.0150)$ & & $(0.0187)$ & $(0.0193)$ & $(0.0180)$ \\
\hline \multirow{2}{*}{ Very small firms (10-19) } & & $-0.248^{* * * *}$ & & & \\
\hline & & $(0.0349)$ & & & \\
\hline \multirow{2}{*}{ Small firms (20-49) } & & -0.0306 & & & \\
\hline & & $(0.0433)$ & & & \\
\hline \multirow{2}{*}{ Medium-sized firms (50-249) } & & $0.637^{* * *}$ & & & \\
\hline & & $(0.0425)$ & & & \\
\hline \multirow{2}{*}{ Large firms $(250+)$} & & $0.285^{* * * *}$ & & & \\
\hline & & $(0.0646)$ & & & \\
\hline \multirow{2}{*}{ Age } & & & $-0.0245^{* * *}$ & $-0.0241^{* * * *}$ & $-0.0251^{* * * *}$ \\
\hline & & & $(0.00613)$ & $(0.00632)$ & $(0.00619)$ \\
\hline \multirow{2}{*}{ Age, squared } & & & $0.0001^{* * *}$ & $0.0001^{* * *}$ & $0.0001^{* * * *}$ \\
\hline & & & $(3.44 \mathrm{e}-05)$ & $(3.52 \mathrm{e}-05)$ & $(3.51 \mathrm{e}-05)$ \\
\hline \multirow{2}{*}{ Far East Region } & & & & $0.0555^{* *}$ & $0.0626^{*}$ \\
\hline & & & & $(0.0231)$ & $(0.0321)$ \\
\hline \multirow{2}{*}{ North Caucasian District } & & & & $-0.208^{* * * *}$ & $-0.206^{* * *}$ \\
\hline & & & & $(0.0565)$ & $(0.0602)$ \\
\hline \multirow{2}{*}{ North West region } & & & & $0.106^{\text {****** }}$ & $0.109^{* * * *}$ \\
\hline & & & & $(0.0206)$ & $(0.0190)$ \\
\hline \multirow{2}{*}{ Siberian region } & & & & $-0.104^{* * * *}$ & $-0.102^{* * * *}$ \\
\hline & & & & $(0.0119)$ & $(0.0143)$ \\
\hline
\end{tabular}




\section{End of table 2}

\begin{tabular}{|c|c|c|c|c|c|}
\hline \multirow{2}{*}{ Dependent variable } & \multicolumn{5}{|c|}{ Labour productivity, $\log$} \\
\hline & $(1)$ & $(2)$ & $(3)$ & $(4)$ & $(5)$ \\
\hline \multirow{2}{*}{ South region } & & & & $-0.136^{* * * *}$ & $-0.135^{* *}$ \\
\hline & & & & $(0.0504)$ & $(0.0571)$ \\
\hline \multirow{2}{*}{ Ural region } & & & & $0.0820^{* * * *}$ & $0.0892^{* * * *}$ \\
\hline & & & & $(0.0101)$ & $(0.0123)$ \\
\hline \multirow{2}{*}{ Volga region } & & & & $-0.108^{* * * *}$ & $-0.103^{* * * *}$ \\
\hline & & & & $(0.0207)$ & $(0.0227)$ \\
\hline \multirow{2}{*}{ Mining } & & & & & $0.847^{* * *}$ \\
\hline & & & & & $(0.188)$ \\
\hline \multirow{2}{*}{ Manufacturing } & & & & & $0.539^{* * * *}$ \\
\hline & & & & & $(0.0936)$ \\
\hline \multirow{2}{*}{ Electricity } & & & & & $1.821^{* * *}$ \\
\hline & & & & & $(0.0493)$ \\
\hline \multirow{2}{*}{ Water, waste management } & & & & & $0.639^{* * *}$ \\
\hline & & & & & $(0.271)$ \\
\hline \multirow{2}{*}{ Construction } & & & & & $0.538^{* * *}$ \\
\hline & & & & & $(0.0711)$ \\
\hline \multirow{2}{*}{ Trade and repairs } & & & & & $0.351^{* * * *}$ \\
\hline & & & & & $(0.0571)$ \\
\hline \multirow{2}{*}{ Transporting and storage } & & & & & $0.866^{* * * *}$ \\
\hline & & & & & $(0.0546)$ \\
\hline \multirow{2}{*}{$\begin{array}{l}\text { Accommodation and food } \\
\text { services }\end{array}$} & & & & & 0.0104 \\
\hline & & & & & $(0.0589)$ \\
\hline \multirow{2}{*}{ Information and communication } & & & & & 0.0878 \\
\hline & & & & & $(0.190)$ \\
\hline \multirow{2}{*}{ Real estate } & & & & & $1.334^{* * *}$ \\
\hline & & & & & $(0.0469)$ \\
\hline \multirow{2}{*}{$\begin{array}{l}\text { Professional and scientific } \\
\text { activities }\end{array}$} & & & & & $-0.513^{* * *}$ \\
\hline & & & & & $(0.130)$ \\
\hline \multirow{2}{*}{ Administration and support } & & & & & -0.345 \\
\hline & & & & & $(0.220)$ \\
\hline Observations & 5773096 & 5773096 & 5772934 & 5772614 & 5772614 \\
\hline$R$-squared & 0.124 & 0.144 & 0.130 & 0.132 & 0.118 \\
\hline $\begin{array}{l}\text { Sector (Nace } 2 \text { rev. 2, 2-digit) } \\
\text { fixed-effect }\end{array}$ & Yes & Yes & Yes & Yes & Yes \\
\hline Year fixed-effect & Yes & Yes & Yes & Yes & Yes \\
\hline Firm fixed-effect & No & No & No & No & No \\
\hline
\end{tabular}

Note. Robust standard errors in parentheses. ${ }^{* * *} \mathrm{p}<0.01,{ }^{* *} \mathrm{p}<0.05,{ }^{*} \mathrm{p}<0.1$. The results report an average effect of the variable on the firm's productivity level.

Source: OECD-Orbis database. 
- Create a climate that is supportive to innovative start-ups.

- Support "resource allocation" by helping unproductive firms to leave the market.

- Foster labour and capital mobility and knowledge transfer between firms and, especially, across regional borders.

- Embrace foreign ownership and facilitate foreign direct investment further.

\section{REFERENCES}

Bajgar M., Berlingieri G., Calligaris S., Criscuolo C., Timmis J. (2019). Industry Concentration in Europe and North America. OECD Productivity Working Papers, 18. Paris: OECD Publishing. DOI: 10.1787/2ff98246-en

Blöchliger H., Durand-Lasserve O. (2018). The drivers of regional growth in Russia: A baseline model with applications. OECD Economics Department Working Papers, 1523. Paris: OECD Publishing. Available at: https://dx.doi. org/10.1787/9279f6c3-en

Brown D., Earle J., Telegdy A. (2006). The productivity effects of privatization: Longitudinal estimates from Hungary, Romania, Russia, and Ukraine. Journal of Political Economy, 114, 61-99.

\section{Fons-Rosen C., Kalemli-Ozcan S., Sorensen B.,} Villegas-Sanchez C., Volosovych V. (2017). Foreign investment and domestic productivity: Identifying knowledge spillovers and competition effects. Working Paper 23643, NBER. Available at: https:// www.nber.org/papers/w23643

Haltiwanger J., Jarmin R., Miranda J. (2011). Who creates jobs? Small vs. large vs. young. Working Paper 16300, NBER. Available at: http:// econweb.umd.edu/ haltiwan/ size_age_paper_R\&R_Aug_16_2011.pdf

Javorcik B. (2004). Does foreign direct investment increase the productivity of domestic firms? In search of spillovers through backward linkages. The American Economic Review, 94 (3), 605-627.

Javorcik B., Spatareanu M. (2008). To share or not to share: Does local participation matter for spillovers from foreign direct investment? Journal of Development Economics, DOI: $10.1016 /$ j.jdeveco.2006.08.005

OECD (2017). Economic policy reforms: Going for growth. Paris: OECD Publishing. DOI: 10.1787 /growth-2017-en

Поступила в редакиию 29.10.2020

Received 29.10.2020 


\section{Х. Блёхлигер}

ОЭСР, Париж, Франция

\section{Л. Вильднерова}

ОЭСР, Париж, Франция

\section{Производительность российских фирм: семь фактов}

Аннотация. Производительность в российской экономике в последние 15 лет последовательно снижалась. В настоящей статье анализируются факторы, определявшие этот процесс на уровне отдельных фирм, и оценивается роль этих факторов в снижении производительности на агрегированном уровне. Основные результаты формулируются в виде семи выводов. Показано, что для предотвращения дальнейшего снижения производительности необходимы регуляторные меры, поддерживающие действие рыночных сил. Следует создать благоприятный климат для появления инновационно активных новых фирм, ускорить уход неконкурентоспособных фирм, повысить мобильность трудовых ресурсов и капитала, а также трансферт знаний между фирмами и регионами, облегчить распространение иностранной собственности в экономике. Такую политику необходимо дополнить адресной поддержкой домашних хозяйств и фирм, особенно пострадавших от кризиса вызванного эпидемией Covid-19. Работа основана на результатах, полученных в рабочем докладе департамента экономических исследований ОЭСР, опубликованном в начале 2020 г.

Ключевые слова: российская экономика, производительность на уровне фирм, разрыв производительности, иностранная собственность, вход и выход фирм на рынок.

JEL Classification: D24, L16, O43.

DOI: $10.31737 / 2221-2264-2020-48-4-11$ 